\title{
The Prospects and Challenges of Economic Liberalization in Reducing Poverty and Inequality in Indonesia
}

\author{
Alfath Bagus Panuntun El Nur Indonesia
}

\begin{abstract}
This article discusses whether economic liberalisation policies have succeeded in alleviating poverty and inequality in Indonesia. In addition, this article aims to provide alternative policies to strengthen Indonesia's bargaining position in international trade forums by shifting the extractive industry to knowledge-based industries and fixing the fragile social protection system when faced with COVID-19. This article is written descriptively and analytically based on various data, such as literature, planning documents, news reports, and other sources. Despite the prospect of economic liberalisation, the findings show Indonesia has three main problems: statistical data that does not reflect reality, overlapping regulations, and weak governance. This article offers several policy recommendations that need improvement based on the "Going for Growth" framework.
\end{abstract}

Keywords: economic liberalisation, poverty alleviation, inequality, social protection, and going for growth

\begin{abstract}
Abstrak
Tulisan ini mendiskusikan apakah kebijakan liberalisasi ekonomi berhasil dalam pengentasan kemiskinan dan ketimpangan di Indonesia. Selain itu, tulisan ini bertujuan untuk memberikan alternatif kebijakan dalam rangka memperkuat posisi tawar Indonesia dalam forum perdagangan internasional dengan menggeser industri ekstraktif ke industri berbasis pengetahuan, sekaligus membenahi sistem perlindungan sosial yang rapuh ketika dihadapkan pada COVID-19. Tulisan ini ditulis secara deskriptif dan analitis berdasarkan dukungan dari berbagai data, seperti literatur, dokumen perencanaan, laporan berita, dan sumber lainnya. Meskipun terdapat prospek dari liberalisasi ekonomi, temuan menunjukkan bahwa Indonesia memiliki tiga masalah utama: data statistikyang tidak mencerminkan realitas, regulasi yang tumpang tindih, dan lemahnya tata kelola pemerintahan. Tulisan ini menawarkan beberapa rekomendasi kebijakan yang perlu ditingkatkan berdasarkan kerangka berpikir "Going for Growth".
\end{abstract}

Kata kunci: liberalisasi ekonomi, pengentasan kemiskinan, ketimpangan, perlindungan sosial dan going for growth

\section{Introduction}

Since 1967, Indonesia has long known how to free its economy by implementing the Foreign Investment Law. Economic liberalisation refers to the government's scheme to build a conducive business universe by removing trade barriers (Woodward, 1992; Cornia, 2003; Ardiansyah, 2014). It is indicated by the importance of foreign direct investment (FDI) and international trade. According to Verico and Pangestu (2020), governments have successfully implemented economic liberalisation in most developing countries to improve their economies. Therefore, this event shows that economic liberalisation has the prospect of reducing poverty and ending inequality.

The Indonesian government's main agenda is reducing poverty and ending inequality, as seen in the National Long-Term Development Plan (RPJPN) for the 2005-2025 period in its fifth mission: "to achieve equitable and development." This mission has been embodied in the 2020-
2024 National Medium-Term Development Plan (RPJMN), Master Plan for the Acceleration and Expansion of Poverty Reduction (MP3KI), and Long-Term/Medium-Term Development Plans at regency/city levels throughout Indonesia. Therefore, the two agendas need serious attention from policymakers.

Poverty and inequality are different, but it is related concepts. Poverty is understood as a person's inability to meet basic needs as measured by expenditure, whereas inequality is an unstable condition in society caused by differences in access to resources (Holden, 2014; BPS, 2020). The relationship lies in the condition that the higher the poverty, the higher the income inequality. In essence, poverty is a factor that significantly influences inequality (Solikatun et al., 2014; Sugiyarto et al., 2015).

In addition, the OECD-WTO created a version, known as the Trade-in Value Added (TiVA), to measure the value of trade based on the extent to which trade provides more incredible benefits, 
Alfath Bagus Panuntun El Nur Indonesia - The Prospects and Challenges of Economic Liberalization in Reducing Poverty and Inequality in Indonesia

such as better jobs, higher incomes, to guarantees a better quality of life (Sturgeon, 2015). They enable a country to overcome poverty and inequality. Today, markets for goods and services are becoming integrated through migration, technological advances, and knowledge transfer. The keyword is the "participation" of developing countries, including Indonesia, in the international trade arena.

In the last three decades, Indonesia has been actively involved in regional and global production networks. Since 1980, Indonesia has implemented a series of policies with economic liberalisation, such as signing several free trade agreements, eliminating various trade barriers, and applying fairer tariffs (Rosser, 2013). Indonesia has also become one of the leading destinations for foreign investment to increase the proportion of foreign ownership and reduce the number of negative lists (Lindblad, 2015). It makes Indonesia more globally integrated, where the trade-to-GDP ratio in 2019 has doubled compared to 1970 (OECD, 2019). In addition, there is an opportunity to form a new ecosystem in the era of the internet of things, for example, digital business that allows millions of Indonesians from various backgrounds to trade or offer services.

However, this study argues that the phenomenon of uncontrolled economic liberalisation can produce counterproductive conditions. In this context, there will be a "growth mirage" where statistics show positive economic growth, but only a few people will benefit (Yustika et al., 2011). Instead of economic growth describing an increase in people's welfare, the practice and reality do not happen. Although Indonesia's economic growth over the last ten years is categorized as favourable compared to other countries with an annual average of $5 \%$, there is a tendency to experience a slowing trend and is below the government's target of 6\% per year (Bappenas, 2019).

In terms of equality, Indonesia is considered one of the most impoverished countries in the world. Increasing income and consumption is believed only to benefit a small part of the community. It is in line with the 2015 World Bank report, which states that inequality in Indonesia is not due to worsening poverty, but the accelerated wealth accumulation of the wealthiest 1\% (Indrakesuma, Janz, \& Wai-Poi, 2015). The report also mentions four factors that exacerbate economic inequality, including birth opportunities, labour market conditions, wealth concentrated in a few people, and the unpreparedness of the poor. This condition is so concerning, especially when faced with COVID-19, which shows the weakness of the social protection system in Indonesia. It means that, as a member of the G-20, Indonesia is still experiencing system barriers, especially the distribution of social services to vulnerable societies. In addition, the state also faces the problem of limited availability of skilled and competitive workers, while on the other hand, there are many uncompetitive and unemployed graduates of the workforce.

Furthermore, it is worth highlighting that Indonesia's economic structure is highly dependent on natural resources. It is in line with the World Economic Forum and PwC (2020) reports, showing that one-third of Indonesia's GDP is generated from economic sectors highly dependent on nature. This dependence is exploitative and indicates future vulnerability when natural resource stocks are depleted. It is further exacerbated by the deterioration of governance in which Indonesia is categorized as a country filled with corruptors, not serious in efforts to eradicate corruption, and the strengthening of domestic political complexities (TI, 2020; Hadiz \& Robinson, 2014).

It needs to be studied further to answer whether the policy of economic liberalisation successfully overcomes efforts to reduce poverty and inequality in Indonesia. This paper will reveal the prospects and challenges of economic liberalisation in overcoming the above problems through four parts: 1) Economic liberalisation and its impact on poverty and inequality; 2) Increasing inequality and social problems in the COVID-19 era; 3) Identify key problems and recommendations, and 4) Conclusion remark.

\section{Theoretical Framework Going for Growth}

This study has two main focuses. First, to analyse whether economic liberalisation policies have succeeded in alleviating poverty and reducing inequality. Second, analyse what policies are appropriate to implement when faced with COVID-19. To answer these two focuses, the author uses the OECD's idea of going for growth in its report entitled "Going for Growth 2021: Shaping a Vibrant Recovery". 
Going for growth was designed in terms "to identify the five top structural reform priorities to boost medium-term economic growth inclusively and sustainably. In addition, it formulates recommendations on how to address these priorities and tracks actions taken" (OECD, 2021). It happens because structural reforms are needed to overcome obstacles by liberalizing the labour market, product, and service so that it is expected to encourage job creation, investment, and productivity (Jeffries \& Rutherglen, 2007; EC, 2021). The essence of this concept is reducing income and opportunity inequalities and poverty to protect social cohesion and citizen well-being, both of which are critical to long-term growth. In addition, environmental problems such as natural exploitation that causes environmental degradation have threatened economic growth and prosperity. This recognition has resulted in a more comprehensive "going for growth" framework over time.

To determine the priority of structural reforms, the concept of going for growth focuses on three dimensions. Firstly, the dimension of growth can be seen in how much productivity and expertise the workforce has. Secondly, the dimension of inclusivity is measured through inclusivity of results and equality of opportunity. Thirdly, the dimension of sustainability is assessed through environmental sustainability. Each dimension is identified to find the outputs and gaps in existing policy performance to obtain a stock of problems. It helps better identify the importance of policy-related compensation on different dimensions and facilitates the presentation of policy priorities in a more comprehensive strategy. Thus, the government can be more precise in choosing the issues to be prioritized.

This concept is considered very flexible and essential when setting priorities, especially for COVID-19 recovery, where reliance on specialised skills is required to offset high uncertainty and time constraints. In addition, this concept is also an entry point for sciencebased economic policies. In recent decades, information and knowledge have become the basis for modern economic developments affecting work processes, labour behaviour, and consumption patterns. Both are even predicted to be the primary key to economic success in the future (Drucker, 1992). For example, in the 1980s, China tried to catch up with developed countries by implementing knowledge-based economic policies to promote growth and competitiveness. Despite experiencing various obstacles, such as weak institutional structures and resources, they struggle to produce knowledge turned into wealth. Now, the results have been seen where they have transformed into a world economic power. Lessons from China have forced Indonesia to evaluate its economic structure to strengthen its bargaining position in international trade and improve its social protection system.

Figure 1

The Going for Growth Framework

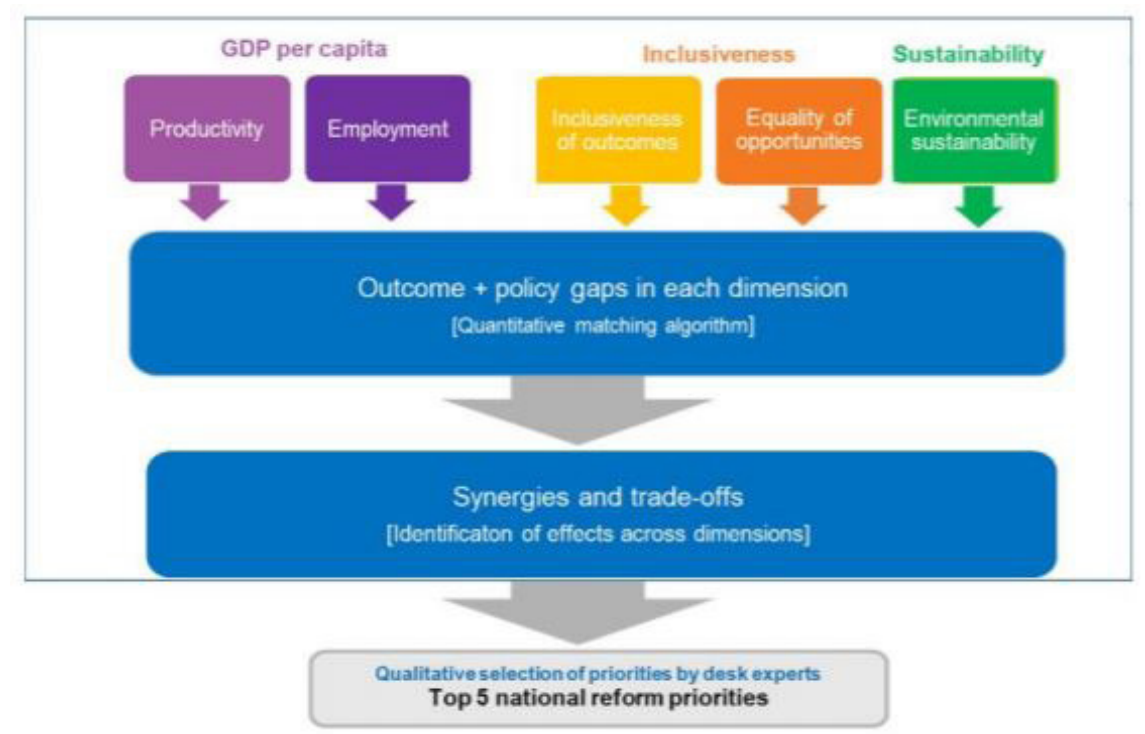

Source: OECD, 2021 
Alfath Bagus Panuntun El Nur Indonesia - The Prospects and Challenges of Economic Liberalization in Reducing Poverty and Inequality in Indonesia

To achieve this goal, "Going for Growth" helps identify the government's policies to achieve inclusive and sustainable economic growth and prioritise the country's current challenges. However, this concept possibly has a gap wherein pursuing growth and redistribution strategies simultaneously, and policymakers need to be aware of the possible complementarity or tradeoff between the two objectives. It concludes that the policies designed need to be considered more carefully but must be enacted to reduce poverty and inequality.

\section{Methods}

Qualitative methods are used in this article. This method allows researchers to empirically describe the relationship between variables in research problems, with much sharpening of shared influences and value patterns encountered (Moleong, 2004, p.5). Then, Cresswell (2009) notes that this method provides three possible problems observed, including permanent, evolving, and ultimately changing. In this context, the researcher tended to develop his research problem when entering the research field, which may be preferable. Specifically, the method used here was a literature review, a type of critical review in which the researcher analyses and evaluates a particular topic (Jesson et al., 2011). A literature review aims to understand the existing research and debates relevant to a specific topic or area of study and present that knowledge in the form of a written report. Thus, conducting a literature review means trying to build knowledge.

As Hart (2001) conveyed, the data in this study were obtained from the selection of documents or files on the ideas and concepts offered to evaluate the findings that had been done previously. The first step taken by the researcher was to collect many pieces of literature as samples that matched the research theme with the keywords "economic liberalisation," "poverty alleviation," "inequality," and "going for growth" through an academic search engine. The literature was in the form of reports, books, scientific articles, to regulations. Furthermore, researchers understood and analysed various findings to generate constructive criticism. Then, the researcher offered an alternative framework of "going for growth" in describing the problem objectively and adhering to the principles of better-applied science. This concept allowed the authors to identify gaps in policy implementation. Thus, this provided a more comprehensive meaning of how the literature review was carried out by selecting various documents or files for the ideas and concepts offered to evaluate the findings previously carried out.

The analysis results were written based on the dilemma between prospects and challenges, thus showing the gap between theory and practice of various economic liberalisation policies in Indonesia and their relation to poverty alleviation and inequality reduction agendas. In addition, the analysis offered several recommendations that the Indonesian government can make to think about better economic growth projections and improve the social protection system, which weaknesses are revealed due to the COVID-19 pandemic.

\section{Result}

Economic Liberalisation and the Impact on Poverty Alleviation and Reducing Inequality

Indonesia Economic Liberalisation Update

Since 1950, Indonesia has implemented a policy of economic liberalisation. It is evidenced by Indonesia's involvement as a member of the General Agreement on Tariffs and Trade (GATT). Also, Indonesia participated in the Uruguay Round, which became the World Trade Organization (WTO) embryo in 1995. Indonesia was one of the founders of the Asia Pacific Economic Cooperation (APEC), which sparked the "Bogor Goals" to facilitate free trade and investment flows (Verico \& Pangestu, 2020). For this reason, it is necessary to conduct a review to measure whether the implementation of economic liberalisation policies is successful or not.

First, it can be seen from the effect of Ease of Doing Business (EoDB) on the amount of foreign direct investment (FDI). So, in 2020, Indonesia aggressively signed some free trade agreements and sought to improve its business climate as directed by the President at the annual session before the People's Representative Council (MPR). According to him, global cooperation is the only option that each country must improve the economy. There are seven achievements made by the Ministry of Trade in international trade cooperation, such as new trade agreements that have begun to be implemented (ASEANHongkong Free Trade Agreement, ASEAN- 
Hongkong Investment Agreement, and IndonesiaAustralia Comprehensive Economic Partnership Agreement), ratified agreements (ASEANJapan Comprehensive Economic Partnership and Indonesia-Mozambique Preferential Trade Agreement), as well as newly signed agreements (Indonesia-Korea Comprehensive Economic Partnership Agreement and Regional Comprehensive Economic Partnership) (Ministry of Trade, 2020; Uly, 2020). The various trade agreements are believed to be able to increase foreign investment interest.

Figure 2

Ease of Doing Business in Indonesia

Source: World Bank, 2020

Then, some steps must be taken simultaneously, such as simplifying regulations, reducing logistics costs, and increasing national electricity electrification. These steps created improvements where Indonesia increased its ranking from 114 in 2015 to 73 in 2020 (out of a total of 190 countries), although the last three consecutive years have been stagnant (World Bank, 2020). The best indicator is "getting electricity," which shows the ease of businesspeople to connect to the electricity grid, while the worst is "starting a business" and "enforcing contracts." However, it should be noted that the EoDB index does not always correlate with an increase in foreign direct investment (Corcoran \& Gillianders, 2014).

Furthermore, FDI is the key to global economic integration because foreign investment creates a relatively stable long-term relationship. Indonesia is considered a country with great potential for foreign investment, especially in the Southeast Asian region, because of raw materials and affordable labour costs. It can be interpreted as a channel for transferring knowledge and technology between countries. At the same time, FDI also opens opportunities for domestic companies to promote their products to international markets.

Total FDI inflows in Indonesia after the 1997-8 Asian financial crisis tended to fluctuate. According to the UNCTAD World Investment Report (2020), FDI investment in Indonesia increased by 14\% between 2018 and 2019, reaching US\$23.4 billion, while FDI shares reached US\$ 232 billion in 2019. The primary sources of FDI in Indonesia are the UK, Japan, China, Hong Kong, Singapore, and Malaysia.

Second, assessing Indonesia's trade performance can be seen through the average export volume per year or long-term trends. Good export performance is reflected in a high

Figure 3

FDI inflows to Indonesia, 1997-2019 (\% GDP)

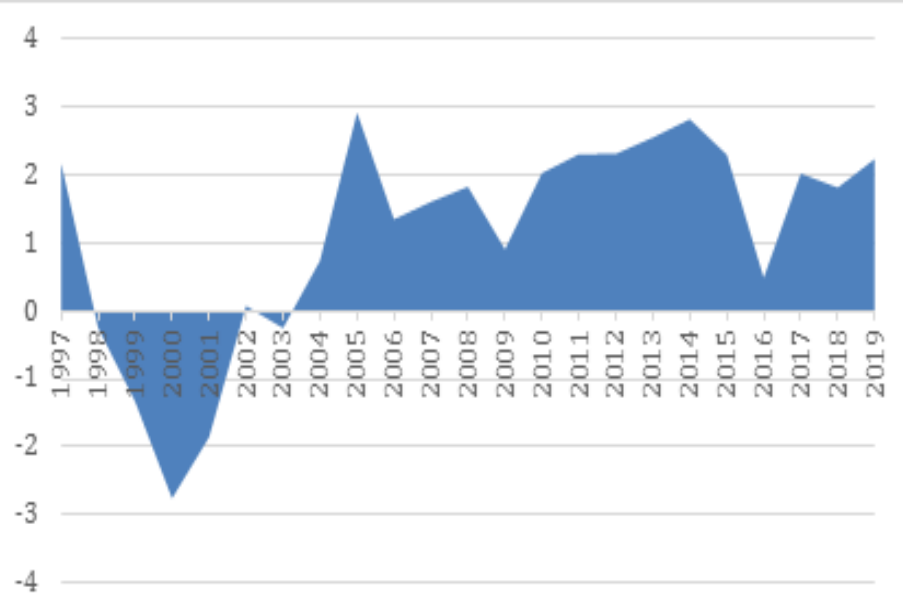

Source: World Bank, 2021 
Alfath Bagus Panuntun El Nur Indonesia - The Prospects and Challenges of Economic Liberalization in Reducing Poverty and Inequality in Indonesia

Table 1

Indonesia Total Exports-Imports in 2019 (in USD millions)

\begin{tabular}{lrrrrrrrr}
\hline \multicolumn{1}{c}{ Months } & Total & Oil \& Gas & $\begin{array}{c}\text { Non-Oil \& } \\
\text { Gas }\end{array}$ & & Total & $\begin{array}{c}\text { Consumption } \\
\text { Goods }\end{array}$ & $\begin{array}{r}\text { Raw } \\
\text { Material } \\
\text { Support }\end{array}$ & $\begin{array}{c}\text { Capital } \\
\text { Goods }\end{array}$ \\
\hline January & $14,028.09$ & $1,131.26$ & $12,896.83$ & $15,005.19$ & $1,220.90$ & $11,427.48$ & $2,356.81$ \\
February & $12,788.56$ & $1,050.78$ & $11,737.78$ & $12,465.07$ & $1,027.76$ & $9,224.29$ & $2,213.03$ \\
March & $14,447.79$ & $1,077.41$ & $13,370.38$ & $13,746.62$ & $1,169.46$ & $10,350.06$ & $2,227.11$ \\
April & $13,068.07$ & 688.11 & $12,379.65$ & $15,399.19$ & $1,460.22$ & $11,570.70$ & $2,368.27$ \\
May & $14,751.89$ & $1,054.24$ & $13,697.65$ & $14,606.66$ & $1,553.19$ & $10,730.75$ & $2,322.72$ \\
June & $11,763.35$ & 714.13 & $11,049.22$ & $11,495.39$ & $1,029.77$ & $8,736.16$ & $1,729.46$ \\
July & $15.238,42$ & $1,400.50$ & $13,837.92$ & $15,518.48$ & $1,465.60$ & $11,272.83$ & $2,780.05$ \\
August & $14,261.96$ & 842.44 & $13,419.12$ & $14,169.35$ & $1,363.84$ & $10,329.97$ & $2,475.55$ \\
September & $14,080.11$ & 803.03 & $13,277.08$ & $14,263.45$ & $1,407.53$ & $10,261.50$ & $2,594.42$ \\
October & $14,881.46$ & 859.95 & $14,021.50$ & $14,759.08$ & $1,436.11$ & $10,881.07$ & $2,441.90$ \\
November & $13,944.49$ & $1,033.73$ & $12,910.76$ & $15,340.48$ & $1,667.81$ & $11,167.80$ & $2,504.87$ \\
December & $14,428.82$ & $1,133.28$ & $13,295.53$ & $14,506.78$ & $1,651.85$ & $10,402.95$ & $2,451.98$ \\
\hline
\end{tabular}

Source: Kemendag, 2020

average growth rate compared to competitors or a positive long-term growth trend. It is because the long-term growth trend reflects the level of product competitiveness in global trade.

During the last ten years, the trend of Indonesia's export growth has fluctuated. Data as of 2019 shows Indonesia's performance with total exports of $167,683.0$ (in a million US\$), while total imports of 171,275.7 (in a million US\$) (Ministry of Trade, 2020; WITS, 2020). This condition indicates Indonesia's trade balance deficit. Therefore, efforts are needed to reform the economy structurally and improve competitiveness to increase productivity, improve infrastructure, and other aspects.

In addition, the way to measure trading performance can be seen through product diversification and market diversification. Indonesia still relies on oil and gas exports, accounting for a third of total GDP, and has not yet targeted a knowledge-based economy. Then, non-oil and gas exports rely on five leading sectors: food and beverages (27.28 million), base metals (17.37 million), textiles and clothing (12.90 million), chemicals, and electronic goods (11. 91 million) (Ministry of Industry, 2020). Meanwhile, imports carried out by Indonesia are still dominated by the need for support for raw materials from outside, followed by capital goods and consumption goods. Thus, Indonesia needs to increase product diversification and market diversification to compete globally and not be trapped in imports.

Third, it can be measured through economic growth, which is a series of changes in economic conditions to increase the value of goods and services on an ongoing basis. Economic growth can be measured by the percentage increase in the gross domestic product (GDP) divided by the total population or per capita income. Over ten years, Indonesia's GDP growth has been consistently at 5\% every year. In December 2019, it was US\$1.119 trillion with a GDP per capita of US\$ 4,193 compared to US\$ 3,945 in December 2018. In this sense, Indonesia was promoted from lower-middle-income economies to uppermiddle-income economies. It was the highest achievement ever achieved in the history of the Indonesian economy. However, the predicate did not last long because of the contraction caused by the COVID-19 pandemic and forced the Indonesian economy to fall back into the middle-income trap (Jiao \& Sihombing, 2021).

The three points above need to be observed to reflect the success of economic liberalisation in Indonesia. The liberalisation process in Indonesia is not the victory of economic rationality over socio-political interests but the socio-political interests that shape economic reform (Rosser, 2003). It means that economic reform in Indonesia occurs because of sociopolitical demands, such as the experience of the 
Figure 4

Annual Change in Extreme Poverty Rates

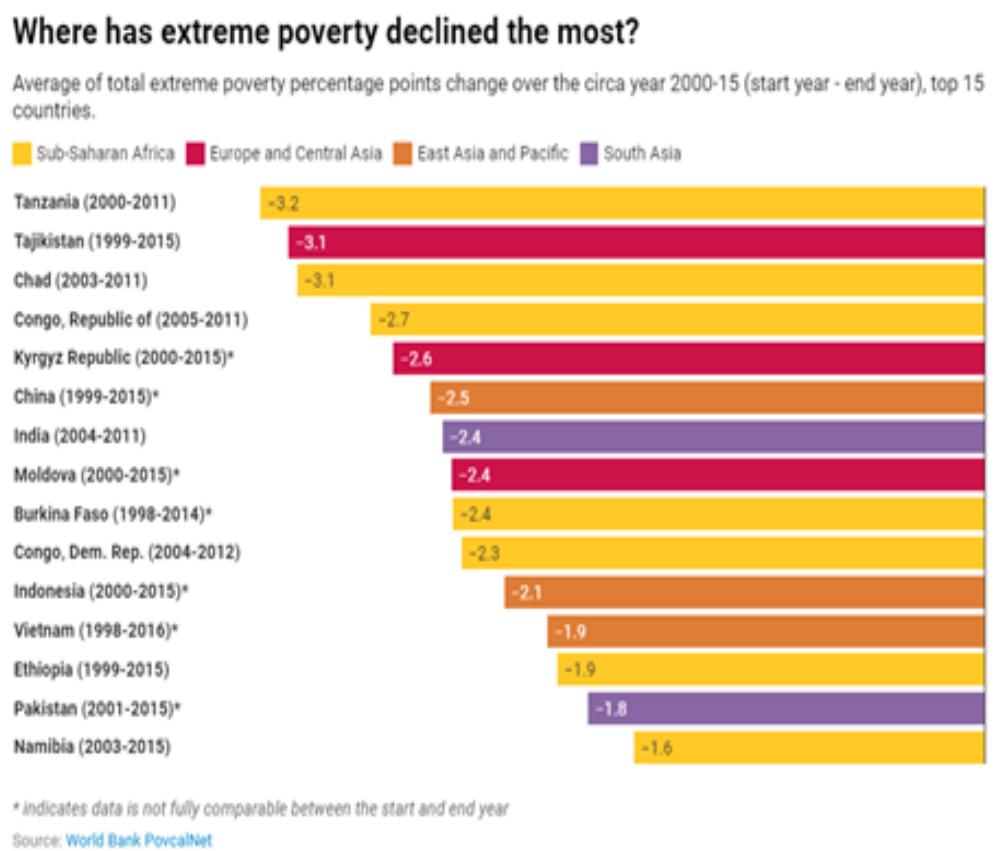

Source: World Bank \& PovcalNet, 2019

multidimensional crisis in the 1960s and 199798 periods (Raditya, 2018; Pramisti, 2020). These demands come from internal factors and external factors from the trend of economic globalisation to the interests of the global elite (Sherlock, 1998).

Finally, it is concluded that economic liberalisation can be seen from two perspectives. On the one hand, economic liberalisation can create prosperity. It is in line with several studies showing that trade liberalisation has increased efficiency, economic growth, and integration (Nurrahma, 2013; Holden, 2014; Verico \& Pangestu, 2020). On the other hand, liberalisation also has side effects in unequal welfare distribution, the possibility of excluding small and medium enterprises, and the lack of protection and a decent salary.

\section{The Impact on Poverty and Inequality}

Economic liberalisation has not only an impact on economic policy but also social policy. Economic growth should encourage improved social development. It is in line with the government's mission to improve the quality of human resources and place humans as the main subject of development. In this way, economic liberalisation policies must consider life's context, dynamics, and sustainability to remain focused on alleviating poverty and narrowing the inequality gap.

\section{a. Poverty Alleviation}

Poverty alleviation is the main agenda of the Indonesian government. The government also claims to have reduced the total poverty rate to below 10 percent (Kemenkeu, 2018). It should be noted that the definition of 'poverty' varies widely and adapts to the context of a country (Lister, 2004). In high-population countries such as Indonesia, where most of the population lives near the poverty line, determining the size of poverty can change perceptions of poverty.

Theoretically, economic liberalisation will benefit developing countries, especially for the poor, because manufactured products will increase. However, the benefits derived from this process depend on reforms of policies and structures of the domestic economy (Winters, 2003). Trade liberalisation encourages economic growth, which in turn helps reduce poverty. It means that poverty alleviation must be considered in planning trade reforms. On the other hand, poverty alleviation strategies should not ignore the trade sector. It has implications for the policies taken by the government.

Increased economic growth is correlated with increased public spending on social affairs. 
Alfath Bagus Panuntun El Nur Indonesia - The Prospects and Challenges of Economic Liberalization in Reducing Poverty and Inequality in Indonesia

The policies carried out by the government, such as the provision of basic needs and the development of the social security system in the period 2000-2015, were considered successful. Indonesia is one of 15 countries that have succeeded in reducing absolute poverty. It is in line with the first mission of the Sustainable Development Goals (SDGs) — reducing absolute poverty to less than $3 \%$ by 2030 . Therefore, social welfare-oriented programs must be strengthened to achieve the target.

The trend of poverty in 2015-2020 also tends to decrease. However, the number of poor

Table 2

Indonesia Relative Poverty and Absolut Poverty

\begin{tabular}{ccc}
\hline Years & $\begin{array}{c}\text { Relative Poverty } \\
\text { (\% from the } \\
\text { population) }\end{array}$ & $\begin{array}{c}\text { Absolute Poverty } \\
\text { (in millions of } \\
\text { people) }\end{array}$ \\
\hline 2015 & 11,22 & 28,59 \\
2016 & 10,86 & 28,01 \\
2017 & 10,64 & 27,77 \\
2018 & 9,82 & 25,85 \\
2019 & 9,41 & 25,14 \\
2020 & 9,78 & 26,42 \\
\hline
\end{tabular}

people in Indonesia in March 2020 increased by 0.56 percent or 1.63 million people compared to the previous period, which was the best achievement in history. It has implications for increasing poverty in rural areas by 0.11 million people and worst in urban areas by 1.17 million people (BPS, 2020). Therefore, poverty alleviation efforts by the government are not over.

\section{b. Uprising Inequality}

The future of Indonesia's welfare is threatened by the widening gap between the rich and the poor. Based on the 2019 Global Wealth Report, Indonesia's Gini coefficient is $83.3 \%$, where the wealthiest $1 \%$ of the population controls $45 \%$ of the total national household wealth. Then, the wealth of every adult in Indonesia has now quadrupled compared to 2000. The wealthiest person's income per day is equivalent to the expenditure of the rest person for a year. Meanwhile, BPS noted that the Gini ratio has fluctuated during the last ten years, although it tended to fall. This condition is not very influential for the wealthy group, but the impact is very pronounced for the rest. It is reinforced by a survey of public perceptions

Figure 5

Wealth Inequality in selected countries

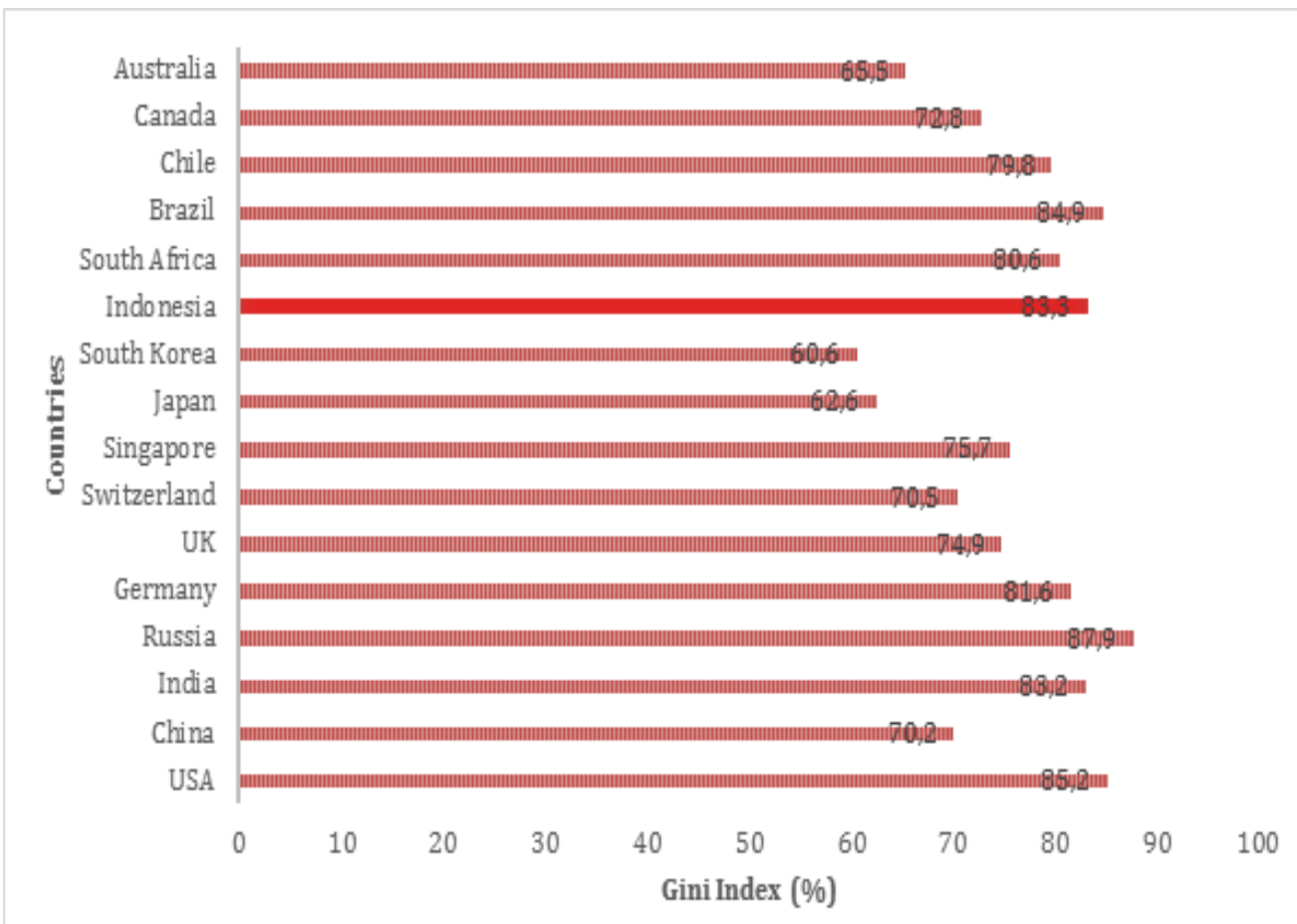

Source: Credit Suisse Global Wealth Report, 2019. 
where as many as $91.6 \%$ of respondents stated that income distribution in Indonesia is "unequal." This response applies to all indicators starting from gender, income, education, age, and location (Suhartadi, 2014). For this reason, if inequality is not addressed, it will lead to social instability.

Indonesia belongs to the middle wealth group and is one of the most impoverished countries behind Russia, the United States, and Brazil. It is evidenced by the distribution of wealth that is concentrated in "Crazy Rich Indonesia," which is the wealthiest $1 \%$ of people or around 115 thousand people and in line with increasing global inequality where the wealthiest $1 \%$ of people in the world control $45 \%$ of the world's assets. The number of these wealthy groups is predicted to increase sharply in the future (Knight Frank, 2021).

Table 3

The Development of Gini Ratio, March 2015-March 2020

\begin{tabular}{cccc}
\hline \multirow{2}{*}{ Years } & \multicolumn{3}{c}{ Gini Ratio } \\
\cline { 2 - 4 } & Urban & Rural & Total \\
\hline 2015 & 0,428 & 0,334 & 0,408 \\
2016 & 0,410 & 0,327 & 0,397 \\
2017 & 0,407 & 0,320 & 0,394 \\
2018 & 0,401 & 0,324 & 0,389 \\
2019 & 0,391 & 0,315 & 0,380 \\
2020 & 0,393 & 0,317 & 0,381 \\
\hline & Source: BPS, 2020
\end{tabular}

If viewed in more detail, Indonesia's Gini Ratio value gradually decreased during the 2015-2020 period. This condition shows an improvement in the distribution of expenditure in Indonesia. Official statistics note that inequality in urban areas is higher than in rural areas. Meanwhile, the province of the Special Region of Yogyakarta (DIY) was the least disadvantaged (0.434), while Bangka Belitung was relatively equal $(0.262)$ (BPS, 2020).

Furthermore, inequality also causes an uneven increase in HDI, as revealed in the UNDP (2019) report. Between 1990 and 2019, Indonesia's HDI increased from 0.525 to 0.718 (rank 107); life expectancy increased from 62.3 years to 71.5 years, the average length of schooling increased from 3.7 years to 8 years, and years of schooling expectations increased from 2.8 years to 12.9 years. However, high inequality makes the poor and vulnerable groups unable to access basic needs and services.

\section{The Cause of Uprising Inequality and Social Problem in Covid-19 Era Unequal Access}

Equality of access and quality is still the primary focus, especially in the COVID-19 era, where differences in access to specific resources cause inequality. It applies at least to two fundamental aspects of human life. First, the fulfilment of adequate and quality education and health services has not been optimal and empirically proven by the limited coverage of services to remote areas. In the education sector, the most urgent problem is the low quality of education caused by the absence of teachers and inadequate school buildings and internet access that has not yet reached remote areas. The same applies to the health sector, where the number of doctors and supporting facilities is limited. The COVID-19 pandemic has revealed the weakness of the health system where many hospitals, especially in Java and Bali, almost collapsed, while many health workers had to die (Al Jazeera, 2021; Cahya, 2021). Indonesia is now referred to as the new epicentre of COVID-19 (Abdurachman et al., 2021).

Figure 6

Social spending as a percentage of GDP in ASEAN and Brazil

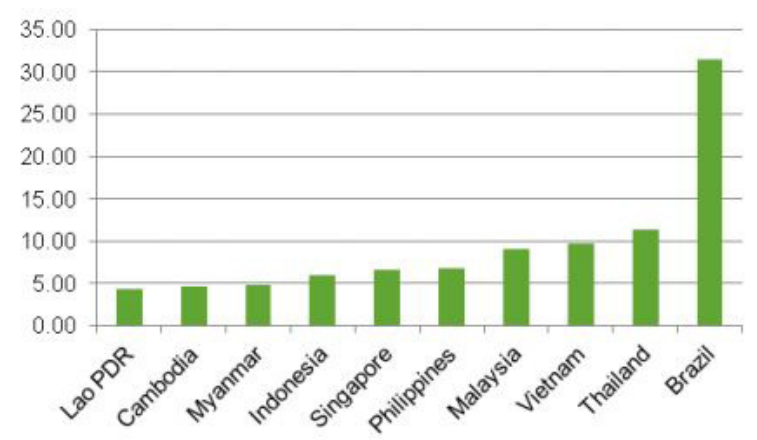

Sumber: Oxfam, 2017

One of the root causes of the problem lies in Indonesia's low social spending compared to several ASEAN countries and Brazil. Today, Indonesia has 47 times more population than Singapore, but Singapore's social spending is much higher. Meanwhile, Indonesia and Brazil have similar geographical and demographic conditions, but Indonesia is far behind social 
Alfath Bagus Panuntun El Nur Indonesia - The Prospects and Challenges of Economic Liberalization in Reducing Poverty and Inequality in Indonesia

spending. The implication is that many people have difficulty accessing services which results in the stagnation of human development. Moreover, the Indonesia social benefits program, Kartu Sakti, is not powerful in helping society due to its limitation of database and funds (Arthurtian, 2014).

Second, the lack of access to infrastructure development and land tenure. Population growth indeed affects the man-land ratio. However, a complex problem arises from agrarian conflicts due to inequality in land tenure and the increasing number of landless farmers (Bachriadi \& Wiradi, 2011). On the one hand, there is a neglect of the reality of the average area of land tenure for the poor, especially farmers $(<0.25 \mathrm{ha})$. On the other hand, there is a tolerant attitude towards the concentration of land ownership by large corporations (51 million ha) (Oxfam, 2017). Thus, agrarian reform is needed to reduce land inequality through land redistribution, land legalization, and social forestry empowerment.

\section{The Labour Market and Unemployment}

The low guarantee of workers' rights and opportunities causes slow economic growth. The average national provincial minimum wage (UMP) in 2020 is Rp. 2,672,370.77 with a value range of Rp.1,704,608.25 - Rp.4,276,349.91 (Ministry of Manpower, 2020). During the
COVID-19 pandemic, labour is one of the most vulnerable professions. Millions of workers have been laid off, while the rest earn meager incomes (Enrico, 2020). Although some trade unions voice the interests of workers, especially in the interests of improving the UMP amid the crisis, there are still many workers in several provinces whose wages do not meet the basic needs of life in Indonesia. In fact, in many cases, industrial relations disputes also occur as unresolved issues (SMERU, 2002).

\section{Control of Natural Resources}

The control of natural resources by a few people and overexploitation of nature are severe problems in Indonesia. It is exacerbated by market fundamentalism, namely the agenda of regulating the entire system of life with the market mechanism as the highest principle, which, according to Polanyi, never really existed (Block \& Somers, 2016). As a result, there is an intensive and extensive commodification of all areas of life.

Furthermore, Indonesia must build awareness not to rely on revenues based on extractive industries, such as oil, gas, and coal. It is because Indonesia's economic structure is highly dependent on natural resources. It is in line with the WEF and PwC (2020) reports which show that a third of Indonesia's GDP is generated from economic sectors that are highly dependent on

Figure 7

Distribution of nature dependency classification by region

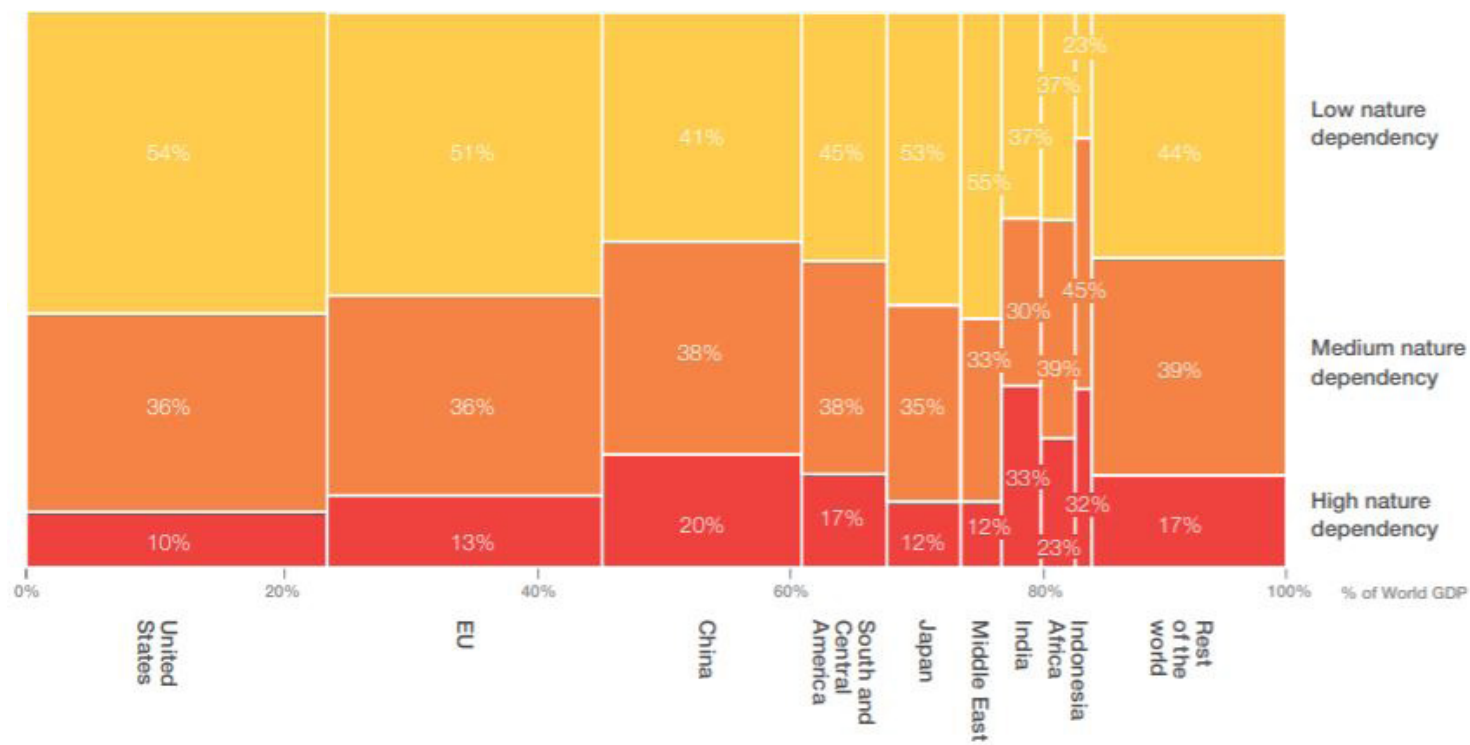

Source: PwC, 2020 
nature. The implication of an extractive economy is extractive politics, which has excluded most societies from political decision-making and equal distribution of welfare. Extractive politics must be shifted to inclusive politics that places people's participation in economic and political life. Thus, inclusive political institutions are needed to achieve sustainable development, such as Britain, America, Australia, France, to Japan (Acemoglu \& Robinson, 2012).

\section{Political Landscape}

The implementation of good governance in Indonesia is still constrained by weak law enforcement and corruption eradication. Transparency International (TI) (2021) released Indonesia's corruption perception index (IPK) in 2020, which was ranked 102 (score: 37), down from the previous year's ranking of 85 (score: 40). The extraordinary crimes evidence that various central and regional officials committed during the pandemic, especially the Minister of Social Affairs Juliari Batubara, corruption in social assistance funds (Sista, 2021). Then, the residue after the 2017 DKI Jakarta gubernatorial and the 2019 presidential elections has divided society. Based on the London School of Economics and Politics (2019) research, divided societies are more likely to ignore and accept inequality. Various hate speeches have ignored the principles and values of humanity. This condition depletes the nation's energy to produce "noise" among citizens rather than "voice," which should be aimed at finding answers to the problems of poverty and inequality.

\section{Discussion}

Key problems and recommendations.

Statistically, economic liberalisation policies alleviate poverty and reduce inequality, but COVID-19 has posed more difficult challenges. The pandemic has made Indonesia's export value decline for the last 1.5 years (BPS, 2021). The existence of a lockdown policy for trading partner countries and social restrictions have hampered the process of economic relaxation, which is still unstable. The liberalisation policy adopted by most of the world's countries has not guaranteed economic conditions that grow positively every year. Similarly, current conditions have revealed the weakness of Indonesia's social protection system. Thus, the struggle to overcome the health and economic crisis is like a "trade-off." Indonesia must choose one of them with careful consideration. Therefore, based on the analysis, three main problems can be revealed in this article, including:

a. Statistical data cannot describe the reality of poverty and inequality

The percentage of poor people in March 2020 was 9.78 percent, but when viewed in detail, the size of poverty in Indonesia was recorded at only Rp. 454.652.-/capita/month or Rp.15,155.-/capita/day. This value is far from the absolute poverty measure set by the World Bank of $\$ 1.90$ or Rp. 27,447.-/capita/ day (exchange rate $\$ 1=$ Rp.14.446.-). It means that absolute poverty in Indonesia far exceeds the government's claim of 26.42 million people, especially when using the moderate poverty measure of $\$ 3.10$; the total poor population is around 100 million people. Furthermore, in The Global Competitiveness Report 2020, it is stated that Indonesia is one of the countries that cannot be measured in terms of social protection in the form of facilities, access, and innovation for the benefit of society and the economy due to the lack of data sources.

b. Regulations are overlapping, complicated, and full of conflict of interests

President Joko Widodo acknowledged that overlapping, convoluted, and conflicting regulations were the leading cause of difficulty in making policy decisions (CNN, 2020). As a result, national development is often hampered, such as the polemic on the import of salt, rice, and beef that keeps recurring because the problem that often arises is the volume of imported products when domestic production is abundant (Anwar, 2018; Pebrianto, 2018; Gumiwang, 2019). The simplification of the rules into the Omnibus Law is still experiencing pros and cons in the society, one of which is related to the minimum limit of $30 \%$ of forest area being removed, which has the potential to increase the conversion of forest area functions in the spatial planning process (Hariandja, 2020). It means that hidden actors take advantage of complex situations, resulting in ineffective government intervention. Moreover, in terms of implementing social restrictions, people are confused with various new terms without adequate social protection. 
Alfath Bagus Panuntun El Nur Indonesia - The Prospects and Challenges of Economic Liberalization in Reducing Poverty and Inequality in Indonesia

c. Weak Governance.

Bureaucratic reform that was echoed after the 1998 crisis is not over. It is evidenced by the decline in Indonesia's GPA (37), especially on democracy and civil liberties indicators. This condition places Indonesia under Singapore (85), Brunei Darussalam (60), Malaysia (51), and even Timor Leste (40) (TI, 2021). There are some influencing factors, such as government integrity, domestic political stability, structural complexity, so forth. Therefore, some policies or interventions made by the government have little impact because they are not built by strong political commitment and scientific support.

The government must address the three major issues raised above by developing a clear framework and measurable plans. The OECD (2019) proposes a "Going for Growth" framework for determining national reform priorities by referring to three dimensions: growth, inclusiveness, and environmental sustainability. Based on the explanation above, the right policies that should be prioritized are as follows.

\section{Conclusion}

This article attempts to explain the policy of economic liberalisation and its impact on poverty alleviation and inequality reduction. In addition, this article analyses what policies are appropriate to implement when the Indonesian government is faced with COVID-19. Based on the explanation and analysis results, there are three conclusions from this study. First, on paper, economic liberalisation is considered prospective in reducing poverty and inequality. However, these data cannot fully describe the fundamental challenges in society due to the difference in measurement standards between Indonesia and the United Nations. Second, this article assesses that the COVID-19 pandemic has revealed the weakness of social protection in Indonesia. Third, the government needs to redesign the right policies by considering the current conditions and the importance of science. This study concludes with five policy recommendations that need to be strengthened: social benefits and activation policies; the rule of law; labour market and minimum wage regulation; product market regulation, competition, trade and FDI openness; and tax structure and efficiency. These five recommendations are expected to increase the government intervention effectiveness and improve people's living standards.

Table 4

Top 5 National Reform Priorities

\begin{tabular}{|c|c|c|}
\hline No. & Agendas & Program \\
\hline 1. & $\begin{array}{l}\text { Social benefits and } \\
\text { activation policies }\end{array}$ & $\begin{array}{l}\text { Integrating "Kartu Sakti" as leading social programs with one integrated data } \\
\text { so that beneficiaries are right on target while at the same time describing } \\
\text { how regional inequality will be addressed between "urban and rural" and } \\
\text { "east and west." } \\
\text { Providing direct cash benefits allocated to purchase nine essential } \\
\text { commodities. } \\
\text { Improving access to essential services and agrarian reform. }\end{array}$ \\
\hline 2. & Rule of Law & $\begin{array}{l}\text { Bureaucratic reform, law enforcement, and human rights and fully support } \\
\text { the agenda of eradicating corruption. } \\
\text { Arrangement of regulations through the Omnibus Law to reduce overlapping } \\
\text { regulations, which is challenging to invest while considering the input of } \\
\text { workers, third sectors, and environmentalists. }\end{array}$ \\
\hline 3. & $\begin{array}{l}\text { Labour market and } \\
\text { minimum wage regulation }\end{array}$ & $\begin{array}{l}\text { Reviewing the UMP by considering purchasing power, inflation, and regional } \\
\text { characteristics. } \\
\text { Revising Indonesian poverty measurement. }\end{array}$ \\
\hline 4. & $\begin{array}{l}\text { Product market regulation, } \\
\text { competition, trade, and FDI } \\
\text { openness }\end{array}$ & $\begin{array}{l}\text { Playing a more critical role in global supply chains by increasing producer } \\
\text { capacity and technology transfer and meeting innovation demands through a } \\
\text { knowledge-based economy. } \\
\text { Encouraging the acceleration of making important trade agreements while } \\
\text { working to increase and expand export markets. }\end{array}$ \\
\hline 5. & Tax structure and efficiency & $\begin{array}{l}\text { Taxing the rich and corporations more. } \\
\text { Gradually increasing the tax ratio to meet the } 20 \% \text { target by } 2030 \text { by } \\
\text { expanding the tax base of individual taxpayers. }\end{array}$ \\
\hline
\end{tabular}

Source: Author, 2021 


\section{References}

Abdurachman, F., Paddock, R. C., \& Suhartono, M. (2021, 17 July). The Pandemic Has a New Epicenter: Indonesia. https://www.nytimes. com/2021/07/17/world/asia/indonesiacovid.html accessed on 18 July 2021.

Aljazeera. (2021, 26 June). Over A Dozen Vaccinated Doctors Dead Amid Indonesia COVID Surge. https://www.aljazeera. com/news/2021/6/26/over-a-dozenvaccinated-doctors-dead-amid-indonesiacovid-surge accessed on 18 July 2021.

Acemoglu, D., \& Robinson, J. A. (2012). Why Nations Fail (1st ed.). New York: Crown Business.

Arthurtian. (2014, 8 November). Kartu Sakti Jokowi Kelemahannya di Validasi Data. https://economy.okezone.com/ $\mathrm{read} / 2014 / 11 / 08 / 320 / 1062743 /$ kartusakti-jokowi-kelemahannya-di-validasi-data accessed on 18 July 2021.

Bachriadi, D., \& Wiradi, G. (2011). Enam Dekade Ketimpangan: Masalah Penguasaan Tanah di Indonesia (1st ed.). Bandung: Agrarian Resource Centre.

Bappenas. (2019). Rencana Pembangunan Jangka Menengah Nasional Periode 20192024. Jakarta: Bappenas. https://www. bappenas.go.id/files/rpjmn/Narasi $\% 20$ RPJMN\%20IV\%202020-2024_Revisi\%20 $14 \% 20$ Agustus\%202019.pdf accessed on 19 July 2021.

Block, F., \& Somers, M. R. (2016). The Power of Market Fundamentalism. Cambridge, MA: Harvard University Press.

BPS. (2020). Profil Kemiskinan di Indonesia Maret 2020. Jakarta: BPS Indonesia. https://www. bps.go.id/pressrelease/2020/07/15/1744/ persentase-penduduk-miskin-maret-2020naik-menjadi-9-78-persen.html accessed on 19 July 2021.

BPS. (2021). Buletin Statistik Perdagangan Luar Negeri Ekspor Menurut Komoditi HS, Mei 2021. https://www.bps.go.id/ publication/download.tml?nrbvfeve= OGQZOWUyNzg 5 YjZiYTA5NT BiZWVi $O W U 3 \& x Z m n=a H R O c H M 6 L y 93 d 3 c u$ YnBzLmdvLmlkL3B1YmxpY2FOaW9uLzIw MjEvMDcvMzAvOGQzOWUyNzg5YjZiYTA5N TBiZWViOWU3L2J1bGV0aW4tc3RhdGlzdGlr LXBlcmRhZ2FuZ2FuLWx1 YXItbmVnZXJpLW Vrc3Bvci1tZW51cnV0LWtvbW9kaXRpLWhz LS1tZWktMjAyMS5odG1s\&twoadfnoarfeauf
$=$ MjAyMSOwOCOyMCAxNjozNjoONw\%3D\% $3 D$ accessed on 20 July 2021.

Cahya, G. H. (2021, 3 July). Indonesia's Hospitals in Covid Crisis As Car Parks Turned Into Emergency Rooms. https: / / www.theguardian.com/globaldevelopment/2021/jul/02/brokenindonesias-hospitals-in-crisis-as-doctorstreat-covid-patients-in-streets accessed on 19 July 2021.

CNN. (2020, 14 August). Jokowi: Regulasi Tumpang Tindih dan Rumit Harus Kita Sudahi. https://www.cnnindonesia.com/ nasional/20200814112752-32-535678/ jokowi-regulasi-tumpang-tindih-dan-rumitharus-kita-sudahi accessed on 18 July 2021.

Commission, E. (2021, 20 July). Structural Reforms for Economic Growth. https:// ec.europa.eu/info/business-economyeuro/growth-and-investment/structuralreforms/structural-reforms-economicgrowth_en accessed on 18 July 2021.

Corcoran, A., \& Gillianders, R. (2014). Foreigne direct investment and the ease of doing business. Review of World Economics, 151(1), pp. 103-126. doi: https://doi.org/10.1007/ s10290-014-0194-5

Creswell, J. W. (2009). Research Design: Qualitative, Quantitative, and Mixed-Method Approaches (3rd ed.). Thousand Oaks: Sage Publications.

Drucker, P. F. (1992). The Age of Discontinuity: Guidelines to our Changing Society (2nd ed.). New York: Routledge. doi: https://doi. org/10.4324/9781315130873

Enrico, B. (2020, 10 June). Impact of COVID-19 Upon Employment Sector in Indonesia. https://iclg.com/briefing/13306-impactof-covid-19-upon-employment-sector-inindonesia accessed on 18 July 2021.

Hadiz, V. R., \& Robinson, R. (2014). The Political Economy of Oligarchy and the Reorganization of Power in Indonesia. in M. Ford, \& T. B. Pepinsky (Editor.), Beyond Oligarchy (pp. 3556). New York: Cornell University Press. doi: https://doi.org/10.7591/9781501719158005

Hariandja, R. (2020, 21 October). Mengapa Lingkungan Hidup Terancam dengan Ada Omnibus Law. https://www.mongabay. co.id/2020/10/21/mengapa-lingkunganhidup-terancam-dengan-ada-omnibus-law/ accessed on 20July 2021. 
Alfath Bagus Panuntun El Nur Indonesia - The Prospects and Challenges of Economic Liberalization in Reducing Poverty and Inequality in Indonesia

Indrakesuma, T. R., Janz, E., \& Wai-Poi, M. G. (2015). A perceived divide: How Indonesians perceive inequality and what they want done about it. Jakarta: The World Bank.

International, T. (2020). Corruption Perception Index: Indonesia. https://www.transparency. org/en/countries/indonesia\# accessed on 19 July 2021.

Jeffries, J. C., \& Rutherglen, G. A. (2007). Structural Reform Revisited. California Law Review, 95, 1387-1422.

Jesson, J. K., Matheson, L., \& Lacey, F. M. (2011). Doing Your Literature Review. Thousand Oaks: Sage Publication.

Jiao, C., \& Sihombing, G. (2021, 8 July). Indonesia Loses Upper-Middle Income Status Amid Pandemic. https://www.bloomberg.com/ news/articles/2021-07-08/indonesialoses-prized-upper-middle-income-statusamid-pandemic accessed on 18 July 2021.

Kemendag. (2020). Ekspor Impor. https:// statistik.kemendag.go.id/export-import accessed on 18 July 2021.

Kemenkeu. (2018). Pertama Kali Dalam Sejarah, Angka Kemiskinan Dibawah Dua Digit. https://www.kemenkeu.go.id/publikasi/ berita/pertama-kali-dalam-sejarah-angkakemiskinan-dibawah-dua-digit/ accessed on 18 July 2021.

Kemenperin. (2020). Dominasi Nilai Ekspor Nasional, Industri Manufaktur Jadi Sektor Andalan. https://www.kemenperin.go.id/ artikel/21592/Dominasi-Nilai-EksporNasional,-Industri-Manufaktur-Jadi-SektorAndalan accessed on 18 July 2021.

Kemnaker. (2020). Rata-Rata UMP Nasional Pada Tahun 2020 Sebesar Rp 2.672.370,77. https://satudata.kemnaker.go.id/details/ data/Rata-Rata\%20UMP\%20Nasional\%20 pada\%20tahun\%202020\%20sebesar\%20 Rp\%202.672.370,77,- accessed on 18 July 2021.

Lister, R. (2004). Poverty (1 ed.). Cambridge: Polity Press.

Lindblad, H. T. (2015). Foreign Direct Investment in Indonesia: Fifty Years of Discourse, Bulletin of Indonesian Economic Studies, 51:2, pp. 217237. doi: 10.1080/00074918.2015.1061913.

Moleong, L. J. (2004). Metodologi Penelitian Kualitatif. Bandung: PT. Remaja.

OECD. (2021). Going for Growth 2021: Shaping a Vibrant Recovery. Paris: OECD. https://www.
oecd.org/economy/growth/OECD-Goingfor-Growth-Framework-2021.pdf accessed on 18 July 2021.

Oxfam. (2017). Towards A More Equal Indonesia. Nairobi: Oxfam.

Rosser, A. (2003). Coalitions, Convergence and Corporate Governance Reform in Indonesia. Third World Quarterly, 24(2), pp. 319-337.

Rosser, A. (2013). The Politics of Economic Liberalization in Indonesia: State, Market and Power. London: Routledge.

Sherlock, S. (1998). Crisis in Indonesia: Economy, Society and Politics. Canberra: Parliament of Australia.https://www.aph.gov.au/About_ Parliament/Parliamentary_Departments/ Parliamentary_Library/Publications_ Archive/CIB/CIB9798/98cib13 accessed on 20 July 2021.

Sista, A. (2021, 27 January). Bancakan Bansos Banteng. https://majalah.tempo.co/ video/17/opini-tempo-bancakan-bansosbanteng accessed on 18 July 2021.

SMERU. (2002). The Practice of Industrial Relations in Indonesia. Employment Friendly Labor Policies for Economic Recovery (pp. 1-33). Jakarta: PEG - BAPPENAS - USAID.

Sturegon, T. (2015, 20 May). World Economic Forum. https://www.weforum.org/ agenda/2015/05/how-can-we-measurethe-value-of-international-trade/ accessed on 20 July 2021.

UNDP. (2020). The Next Frontier: Human Development and the Anthropocene. New York: UNDP. http://hdr.undp.org/sites/all/ themes/hdr_theme/country-notes/IDN.pdf accessed on 18 July 2021.

Verico, K., \& Pangestu, M. E. (2020). The Economic Impact of Globalisation in Indonesia. ERIA Discussion Paper Series, 338(11), pp. 1-31.

Winters, L. A. (2003). Trade Liberalisation and Poverty: What are the Links?. The World Economy, 25(9),pp. 1339-1367. doi: https:// doi.org/10.1111/1467-9701.00495

Yustika, A. E., Hartati, E. S., Listiyanto, E., Firdaus, A. H., Pulungan, A. M., Talattov, A. P., . . . Sumarto, A. H. (2011). Proyeksi Ekonomi Indonesia: Badai Krisis Ekonomi dan Jebakan Liberalisasi. Jakarta: INDEF. https://indef. or.id/source/research/Buku\%20PEI\%20 2012.pdf accessed on 18 July 2021. 